\title{
0 Aluno UnIVERSTTÁRIO e SuAS QueSTÕeS
}

\author{
Joly, M.C. R. A., Santos, A. A. A. \& Sisto, F. F. (orgs.), (2005). Questões do Cotidiano \\ Universitário. São Paulo: Casa do Psicólogo, 264 p.
}

Tendo como pressuposto que todos os envolvidos com o processo de aprendizagem no ensino superior devem assumir a responsabilidade de fazer não apenas o possível, mas o melhor, os organizadores deste livro Maria Cristina R. A. Joly, Acácia Angeli A. dos Santos e Fermino F. Sisto, apresentam por meio dos 12 capítulos que compõem o livro, pesquisas recentes conduzidas por profissionais de Psicologia e áreas afins. Estas desvelam questões do atual cotidiano do ensino superior e suas relações com estudante universitário.

$\mathrm{Na}$ apresentação os organizadores tecem reflexões sobre a atual crise da educação superior, que passa por transformações na busca de uma nova identidade envolvendo seus principais atores, a saber alunos e professores. Destacam que as escolhas feitas para compor os capítulos do livro foram norteadas pelo objetivo de convidar o leitor a pensar no espaço universitário não tão somente como um transmissor de conteúdo e práticas, mas primordialmente um local de formação profissional.

O capítulo inicial "Barreiras a criatividade e traços de personalidade em universitários", de autoria dos organizadores, relata pesquisa realizada com alunos universitários, tendo como pressuposto teórico que personalidade e criatividade estão correlacionados. Os resultados indicam que os fatores tempo, falta de oportunidade e inibição/timidez criam barreiras a criatividade, pois dificultam a expressão da mesma. Quanto ao traço de personalidade verifica-se que os estudantes ingressantes apresentam tendência a serem amistosos, apresentando alta pontuação no fator extroversão.. O tema continua no capítulo 6 "Investigando barreiras à criatividade com universitários ingressantes", no qual as autoras Paula B.C. Guerra e Maria Cristina R. A. Joly, relatam a investigação das barreiras à criatividade em universitários ingressantes.
Destaca-se que dentre os fatores identificados, o fator tempo aparece novamente como uma das mais importantes barreiras externas que influenciam a criatividade.

O uso de estratégias de aprendizagem com o objetivo de melhorar a competência e a compreensão em leitura dos alunos é apresentado em "Avaliação do uso de estratégias de aprendizagem e a compreensão em leitura de universitários", titulo do capítulo dois. O assunto volta a ser discutido no capítulo 12 "Estratégias de Aprendizagem: Contribuições para a formação de professores nos cursos superiores". Nestes as autoras enfocam a importância das estratégias metacognitivas, tanto na identificação do seu uso pelos alunos, como apresentam ao leitor os princípios gerais de um modelo de intervenção em estratégias de aprendizagem, que os professores podem ensinar aos alunos, para ele possa escolher as estratégias que se adequam ao seu perfil pessoal e usá-las para o melhor entendimento dos textos acadêmicos.

"Estilos cognitivos dependência e independência de campo: análise de sua relação com a compreensão da leitura", é o título do capítulo 3 . O estilo cognitivo dependência de campo caracteriza o individuo que prefere uma estrutura externa de referência. Já os indivíduos que dão preferência a uma independência de campo, contam com uma estrutura interna de referência. A habilidade de compreensão em leitura entre universitários e a possibilidade dela estar relacionada com os estilos cognitivos pessoais, neste capítulo as autoras exploram as relações entre estes dois construtos.

Preocupados com o cenário que os professores universitários se deparam no que tange a dificuldade dos alunos em debater, criticar, ler e produzir textos utilizando um raciocínio coerente e bem elaborado, no 
capítulo 4 "Produção de texto e inteligência fluída", os autores apontam as possíveis relações entre as medidas de produção de texto e a escala de inteligência fluida. A escrita é também o assunto do capítulo seguinte "Habilidade em escrita: um estudo com universitários ingressantes". Os autores relatam estudo realizado com universitários ingressantes, neste confirmaram o que a literatura sobre a área apontava, detectaram que os alunos que chegam ao nível com sérios problemas quanto as habilidades de produção escrita, apresentando grandes e elevados números de erros gramaticais em suas produções.

No capítulo 7 "Condutas agressivas e gênero: Uma questão de estilo de agressividade", os autores trazem contribuições provenientes da literatura e de estudo realizado sobre a agressividade com estudantes universitários, cabe destacar que neste nível escolar são poucas as pesquisas realizadas no Brasil e quando realizadas geralmente é o professor que discorre sobre as condutas agressivas dos alunos, neste estudo foram os próprios alunos que relataram suas condutas. O estudo indica que as condutas agressivas autopercebidas pelos universitários homens são importunar outras pessoas, destruir coisas que não lhe pertencem, enganar e violar regras, desrespeitar a segurança própria e a alheia. Entre as mulheres estudantes as principais características são a manipulação, a irritabilidade, ataques de birra para alcançar os objetivos, brigas excessivas, humor deprimido e baixa tolerância a frustrações.

Identificar como universitários os ingressantes vivenciam o processo de integração acadêmica nas dimensões pessoais, interpessoais e institucionais, possibilita aos envolvidos na condução do ensino superior uma melhor compreensão e condução da transição do aluno do ensino médio para o nível superior, buscando sua melhor adaptação, permanência e realização acadêmica. Esta é a contribuição que os autores do capítulo 8 "Questionário de vivência acadêmica: estudo de consistência interna do instrumento no contexto brasileiro" nos trazem.

O capítulo seguinte "Percepção de estudantes evadidos sobre sua experiência no ensino superior" descreve a percepção que os estudantes evadidos têm sobre sua experiência no ensino superior. A pesquisa das autoras aponta que a evasão do ensino superior é um processo que envolve complexas interações entre fatores relacionados ao estudante, a instituição e aos eventos externos. O conhecimento e identificação destes fatores possibilitarão a universidade promover um ambiente que desperte no estudante confiança, empenho e bom rendimento, buscando diminuir o alto índice de evasão no ensino superior.

"Concepção e prática do lazer em alunos universitários" é o titulo do capítulo 11. Nele diante da escassez de pesquisa no Brasil sobre o tema nesta área, Miguel Cardozo do Lago e Fermino Fernandes Sisto apresentam os resultados de pesquisa realizada com estudantes da área de Educação Física. Para os universitários deste curso o lazer é considerado um fator de grande importância, relatam que praticam atividades de lazer até duas vezes ao dia, média acima do verificado em pesquisas com estudantes de outras áreas, destaca-se no entanto, que devido as características do próprio curso a atividade física teve maior conotação dentre as demais categorias de lazer, destoando do que é sugerido na literatura para que haja um equilíbrio entre as atividades de lazer manual, intelectual, social, artístico, físico e turístico.

O capítulo seguinte "A motivação dos alunos em cursos superiores", é resultado de um levantamento bibliográfico realizado pelo autor José Aloyseo Bzuneck. Baseado nos resultados de um conjunto de pesquisas sobre motivação escolar, é traçado um esboço da produção cientifica no Brasil e exterior, identificando suas contribuições e limitações. Constata-se que nos estudos internacionais os construtos mais focalizados são metas de realização, motivação intrínseca e motivação extrínseca, o mesmo ocorre no Brasil. Como contribuições destacam-se os dados descritivos, a relação encontrada entre motivação e estratégias de aprendizagem, e o fato de as pesquisas contemplarem diversos cursos superiores. No âmbito das limitações é apontado no aspecto metodológico a ausência de observações diretas, o largo uso de escalas likert, com tendência à analise fatorial e aplicação do alpha de Cronbach.

Questões do cotidiano universitário é um livro que revela a preocupação dos pesquisadores em compreender as dificuldades que os estudantes apresentam ao chegar ao nível superior e seus déficits escolares, propõem ações efetivas que melhorem o desempenho acadêmico, mas que acima de tudo, que possibilitem a estes que ao concluírem seus cursos, possam integrar plenamente o mercado de trabalho. 
É notória a preocupação dos autores de todos os capítulos de tratar os assuntos com profundidade, localizando suas fontes, permitindo ao leitor ampliar os temas discutidos. Constitui-se de um instrumento de informação útil a docentes, coordenadores e administradores do ensino superior, pesquisadores e todos os interessados no processo de ensinoaprendizagem.

Janete Ap. Silva Marini Mestranda do Programa de Pós-graduação em Psicologia da Universidade São Francisco. 